\title{
INTERAKSI ANTARA EKSTRAK AIR BAWANG MERAH (Allium cepa L) DENGAN AIR KELAPA (Cocos nucifera) DALAM MENUNDA SENESCENE POLONG KACANG KAPRI (Pisum sativum $\mathrm{L}$ ).
}

\author{
Anindya Rahma ${ }^{1)^{\star}}$, Zulkifli' ${ }^{1)}$, Martha L. Lande ${ }^{1)}$, Endang Nurcahyani ${ }^{1)}$ \\ 1) Jurusan Biologi FMIPA Universitas Lampung \\ *E-mail : Anindyarahma234@gmail.com
}

\begin{abstract}
This study aims to determine whether a mixture of red onion water extract and coconut water can delay senescence of pea bean pods. The research was conducted in Botanical Laboratory, Department of Biology, Faculty of Mathematics and Natural Sciences, University of Lampung in October 2017. The research was arranged in $3 \times 3$ factorial design. Factor $A$ is coconut water with concentration $0 \% v / v, 25 \% v / v, 50 \% v / v$. Factor $B$ is an onion water extract with a concentration of $0 \% \mathrm{v} / \mathrm{v}, 12.5 \% \mathrm{v} / \mathrm{v}, 25 \% \mathrm{v} / \mathrm{v}$. The variables in this research are fresh weight, dry weight, relative water content, total chlorophyll content of peas pods. The quantitative parameters in this study were all the mean $(\mu)$ variable. Homogeneity variation was determined by Levene test at $5 \%$ real level. Tukey's variety and assay analysis was performed at a real 5\% level. The results showed that onion water extract, coconut water, and its interaction had no significant effect on the fresh weight of beans, but the interaction between onion and coconut water extracts had a significant effect on fresh weight. Likewise, the treatment of water extract of onion and coconut water did not significantly affect the relative water content of the peanut pod, but the interaction both had a real effect on both. From the results of the study it was concluded that the addition of red onion water extract can not increase the ability of coconut water in delaying the process of senescence of pea pods indicated by the decrease of total chlorophyll content and dry weight.
\end{abstract}

Keywords: Senescence, Peas, Red Onion Water Extract, Coconut Water

\section{PENDAHULUAN}

Kacang-kacangan atau disebut juga polongan termasuk famili Leguminosae. Kacang-kacangan mengandung sejumlah besar serat pangan yang jika terlarut dapat membantu menurunkan kadar kolesterol. Kacang-kacangan bersifat rendah kalori, rendah lemak, serta rendah garam natrium. Kacang-kacangan juga mengandung protein, karbohidrat kompleks, folat, dan besi salah satu contonya yaitu kacang kapri. Kacang Kapri (Pisum sativum L. ssp. sativum, suku polong-polongan atau Fabaceae) adalah sejenis tumbuhan sayur yang mudah dijumpaidi pasar-pasar tradisional Indonesia. Kapri masih satu jenis dengan ercis dan termasuk salah satu sayuran yang paling diminati untuk dikonsumsi manusia. Kacang Kapri (Pisum sativum L.)merupakan suku polong-polongan atau Fabaceae adalah sejenis tumbuhan sayur yang mudah di- jumpai di pasar-pasar tradisional Indonesia. Kapri termasuk dalam golongan sayur buah, artinya buahnya yang dimakan sebagai sayur dan tidak digolongkan sebagai buah-buahan,seperti juga tomat atau cabai. Buah ini, yang bertipe polong (legume), dipanen ketika masih muda dan bijinya belum berkembang penuh, sehingga berbentuk pipih dan masih lunak.

Kacang kapri yang dipanen dalam keadaan segar harus segera didistribusikan menuju berbagai tempat untuk memenuhi permintaan konsumen, dalam proses ini biasanya polong kacang kapri rentan mengalami kerusakan misalnya perubahan warna akibat layu. Oleh karna itu untuk tetap menjangakualitaskacang kapri tetap bagus hingga sampai kekonsumen perlu penangan yang tepat untuk menjaga kualitasnya. Menunda kelayuan tanaman dapat menggunakan bahan-bahan 
preservative (pengawet) sebagai tindakan utama pascapanen. Penundaan kelayuan dapat dilakukan dengan menambahkan hormon yang dapat menghambat kelayuan seperti giberelin dan sitokinin (Eason.2002). selain senyawa diatas diketahui bahwa bawang merah memiliki kandungan senyawa quersetin golongan dari flavonoid yang mampu menghambat degradasi atau kelayuan.

Berdasarkan uraian diatas, maka dilakukan penelitian untuk mengetahui pengaruh pemberian kombinasi ekstrak bawang merah dan air kelapa terhadap penundaan Senescence pada polong kacang kapri baik dalam proses distribusi hingga ketangan konsumen. Sehingga mampu menungkatkan nilai jual kacang kapri.

\section{METODE PENELITIAN}

Penelitian ini telah dilaksanakan di Laboratorium Botani Jurusan Biologi Fakultas Matematika dan Ilmu Pengetahuan Alam Universitas Lampung dari bulan Oktober sampai November 2017. Bahan-bahan yang digunakan dalam penelitian ini adalah bawang merah, air kelapa, kacang kapri yang didapat dari pasar tradisional di Bandar Lampung,, aquades, kertas saring Whatman no.1, kertas lebel dan alkohol 95\%. Penelitian ini dilakukan dalam percobaan faktorial $3 \times 3$. Faktor $A$ adalah air kelapa dengan 3 taraf : $0 \% \mathrm{v} / \mathrm{v}, 25 \%$ $\mathrm{v} / \mathrm{v}, 50 \% \mathrm{v} / \mathrm{v}$. Faktor B adalah ekstrak air bawang merah dengan 3 taraf konsentrasi: $0 \% \mathrm{v} / \mathrm{v}, 12,5 \%, 25 \% \mathrm{v} / \mathrm{v}$. Setiap kombinasi perlakuan diulang sebanyak 3 kali sehingga diperoleh satuan percobaan sebanyak 27. Variable dalam penelitian ini adalah berat segar, berat kering, kadar air relative, dan kandungan klorofil total dari polong kacang kapri sedangkan sebagai parameter kuantitatif dalam penelitian ini adalah semua nilai tengah $(\mu)$ variable. Larutan stok air bawang merah dibuat dengan memblender 500 gram bawang merah yang telah dikupas $+500 \mathrm{ml}$ aquades sampai halus. Selanjutnya ekstrak disaring dengan kain kassa kedalam Erlenmeyer. Selanjutnya ekstrak disaring kembali dengan kertas saring Whatman no.1 kedalam Erlenmeyer, sehingga diperoleh ekstrak bawang merah yang relatif jernih. Ekstrak yang diperoleh merupakan larutan stok dengan konsentrasi $100 \% \mathrm{v} / \mathrm{v}$. untuk mendapatkan konsentrasi sesui perlakuan dilakukan pengenceran seperti Tabel 1:

Tabel 1. Susunan pengenceran ekstrak air bawang merah

\begin{tabular}{|c|c|c|}
\hline Konsentrasi & $\begin{array}{l}\text { Volume } \\
\text { larutan } \\
(\mathrm{ml})\end{array}$ & $\begin{array}{l}\text { Volume } \\
\text { aquades } \\
(\mathrm{ml})\end{array}$ \\
\hline $0 \% \mathrm{v} / \mathrm{v}$ & 0 & 100 \\
\hline $12.5 \% \mathrm{v} / \mathrm{v}$ & 12.5 & 87.5 \\
\hline $25 \%$ v/v & 25 & 75 \\
\hline
\end{tabular}

Larutan stok air kelapa dibuat dengan menyaring air kelapa sebanyak $800 \mathrm{ml}$ dengan kertas saring Whatman no.1 sehingga diperoleh larutan stok air kelapa dengan konsentrasi 100\%. Untuk mendapatkan konsentrasi sesuai perlakuan dilakukan pengenceran pada tabel 2.

Tabel 2. Susunan pengenceran air kelapa

\begin{tabular}{lll}
\hline Konsentrasi & $\begin{array}{l}\text { Volume air } \\
\text { kelapa }(\mathrm{ml})\end{array}$ & $\begin{array}{l}\text { Volume } \\
\text { aquades } \\
(\mathrm{ml})\end{array}$ \\
\hline $0 \% \mathrm{v} / \mathrm{v}$ & 0 & 100 \\
$25 \% \mathrm{v} / \mathrm{v}$ & 25 & 75 \\
$50 \% \mathrm{v} / \mathrm{v}$ & 50 & 50 \\
\hline
\end{tabular}

Pada setiap gelas plastik yang berjumlah 27 buah, dimasukan $500 \mathrm{ml}$ pengenceran ekstrak air bawang merah sesuai konsentrasinya, kemudian ditambah dengan $800 \mathrm{ml}$ pengenceran air kelapa sesuai dengan konsentrasi yang telah ditentukan. 1 polong kacang kapri dimasukkan kedalam masing-masing gelas plastik dan dibiarkan selama 4 jam. Selanjutnya polong kacang kapri tersebut diangkat dan ditaruh dicawan petri yang telah diberi label perlakuan dan ulangan. Pengamatan dilakukan setelah 3 hari dengan pengamatan parameter berat segar, polong kacang kapri ditimbang 
berat segarnya menggunakan neraca digital dinyatakan dengan satuan gram. Berat kering, polong kapri yang sudah diukur berat segarnya dikeringkan menggunakan oven selama 3 jam dengan suhu $105-120^{\circ} \mathrm{C}$ untuk menghilangkan kadar air didalam polong kapri.

Selanjutnya ditimbang kembali menggunakan timbangan digital sebagai berat kering. Kadar air relatif menurut Yamasaki dan Dillenburg (1999) dapat dihitung menggunakan rumus berikut

$$
\text { Kadar air relative }=\frac{M 1-M 2}{M I} \times 100 \%
$$

Kandungan klorofil. Penentuan kandungan klorofil menggunakan metode menurut wintermans dan de mots (1965) dilakukan dengan cara menggerus 0,5 gram polong kapri dalam mortal, kemudian ditambahkan $50 \mathrm{ml}$ alcohol 95\%. Ekstrak disaring didalam Erlenmeyer. Sisa gerusan yang masi tertinggal didalam saringan digerus kembali, kemudian disaring kembali. Volume disusuaikan menjadi 100\% dengan menambahkan alcohol 95\%. Ekstrak siap ditentukan kandungan klirofil a, klorofil b. kandungan klorofil ditentukan dengan cara diukur absorbansinya pada panjang gelombang 649 dan $665 \mathrm{~nm}$. Kandungan dan dihitung berda-sarkan persamaan berikut :

$$
\text { ChI }_{\text {tot }}: 20,0 . A 649-6,10 . A 665\left(\frac{v}{w \times 1000}\right)
$$

Analisisa data. Uji Homogenitas ragam (uji Levene) dan analisis ragam dilakukan pada taraf nyata $5 \%$. Jika interaksi faktor A dan faktor B tidak nyata maka ditentukan main efek masing-masing faktor dengan uji BNJ pada taraf nyata $5 \%$. Jika interaksi kedua faktor nyata maka ditentukan iteraction comparision ekstrak air bawang merah pada setiap konsentrasi air kelapa dengan uji Tukeypada taraf nyata 5\%.

\section{HASIL DAN PEMBAHASAN}

Efek penundaan senescence oleh sitokinin telah diketahui dengan baik namun bagaimana proses ini terjadi masih belum jelas (Zwack and Rashotte, 2013). Air kelapa diketahui mengandung hormone sitokinin dalam jumlah yang cukup significant sehingga dapat menunda proses senescence pada tingkat sel dan jaringan tanaman (Woodson et al, 1991). Senescence tumbuhan pada level organ dimanifestasikan dalam perubahan yang spektakuler dalam warna daun (Jeyapalan and Sedivy, 2008). Bawang merah diketahui mengandung senyawa quercetin yang merupakan tergolong ke dalam kelompok flavonols yang diketahui bersifat sebagai anti oksidan (Lakhanapal dan Rai, 2007). Dalam penelitian ini efek kombinasi antioksidan quercetin dari umbi bawang merah dengan hormone sitokinin dari air kelapa terhadap senescence polong kacang kapri dievaluasi berdasarkan perubahan kandungan klorofil total, berat segar, berat kering, dan kadar air relatif.

Korofil total. Efek ekstrak air bawang merah dan air kelapa terhadap klorofil total polong kacang kapri ditunjukan pada table 3. Analisis ragam pada taraf nyata $5 \%$ menunjukan bahwa air kelapa tidak berpengaruh nyata terhadap kandungan klorofil total sedangkan ekstrak air bawang merah serta interaksinya berpengaruh nyata terhadap kandungan klorofil total polong kacang kapri $(\mathrm{P}<0.05)$. linteraction comparison ditunjukan pada Tabel 3.

Hasil penelitian menunjukan bahwa ekstrak air bawang dengan konsentrasi $25 \%$ menurunkan kandungan klorofil totall dari 0.76 menjadi $0.25 \mathrm{ml} / \mathrm{g}$ jaringan atau sebesar $67 \%$. Interaksi antara ekstrak air bawang merah $25 \%$ dengan air kelapa $25 \%$ menurunkan kandungan klorofil total polong kacang kapri dari 0.80 menjadi $0.18 \mathrm{ml} / \mathrm{g}$ jaringan atau sebesar $97 \%$. Demikian juga interaksi antara ekstrak air bawang 25\% dengan air kelapa 50\% menurunkan kandungan klorofil total 
Tabel 3. Rata - rata klorofil total polong kapri 3 hari setelah perlakuan $(\mathrm{mg} / \mathrm{g}$ jaringan)

\begin{tabular}{ccc}
\hline $\begin{array}{c}\text { Air } \\
\text { kelapa }\end{array}$ & $\begin{array}{c}\text { Ekstrak air } \\
\text { bawang } \\
\text { merah }\end{array}$ & $\begin{array}{c}\text { Rata }- \text { rata } \\
\overline{\mathrm{Y}} \pm \text { SE }\end{array}$ \\
\hline $0 \%$ & $0 \%$ & $0.77 \pm 0.03^{\mathrm{a}}$ \\
& $12.5 \%$ & $0.74 \pm 0.04^{\mathrm{a}}$ \\
& $25 \%$ & $0.25 \pm 0.03^{\mathrm{b}}$ \\
$25 \%$ & $0 \%$ & $0.81 \pm 0.02^{\mathrm{a}}$ \\
& $12.5 \%$ & $0.57 \pm 0.19^{\mathrm{a}}$ \\
& $25 \%$ & $0.18 \pm 0.01^{\mathrm{ab}}$ \\
$50 \%$ & $0 \%$ & $0.75 \pm 0.02^{\mathrm{a}}$ \\
& $12.5 \%$ & $0.29 \pm 0.02^{\mathrm{a}}$ \\
& $25 \%$ & $0.24 \pm 0.01^{\mathrm{b}}$
\end{tabular}

Keterangan : nilai yang diikuti dengan keterangan huruf yang sama tidak berbeda nyata

polong kacang kapri dari 0.74 menjadi $0.24 \mathrm{ml} / \mathrm{g}$ jaringan atau sebesar $67 \%$. Cincin B-monohidroksi flavonoid terlibat dalam degradasi asam amino asetat (IAA). Sedangan Cincin B-dihidroksi flafonoid menghambat aktivitas degradasi IAA. Diketahui bahwa peran flavonoid sebagai regulator endogen transfoe auksin (Andersen and Markham, 2006). Oleh sebab itu pemberian air kelapa meningkatkan degradasi IAA sehingga mengngurangi kemampuan air.

\begin{tabular}{lllll}
\hline Faktor & \multicolumn{5}{l}{ Ekstrak air bawang merah } \\
\cline { 2 - 5 } & Taraf & $0 \%$ & $12,5 \%$ & $25 \%$ \\
& $(\mathrm{v} / \mathrm{v})$ & & & \\
Air & $0 \%$ & $0.75 \pm$ & $0.35 \pm$ & $0.59 \pm$ \\
Kelapa & & 0.18 & 0.09 & 0.13 \\
& & & & \\
& $25 \%$ & $0.30 \pm$ & $0.52 \pm$ & $0.53 \pm$ \\
& & 0.08 & 0.10 & 0.07 \\
& $50 \%$ & $0.45 \pm$ & $0.47 \pm$ & $0.51 \pm$ \\
& & 0.05 & 0.08 & 0.11 \\
\hline
\end{tabular}

Analisis ragam pada taraf nyata 5\% menunjukan bahwa air kelapa, ekstrak air bawang merah serta interaksinya tidak berpengaruh nyata terhadap berat segar polong kacang kapri ( $P>0.05)$. Hal ini sesuai dengan haril penelitian Silvinia dkk, 2013, yang menunjukan bahwa pemberian air kelapa tidak berpengaruh terhadap berat segar bunga krisan putih (Dendranthema grandiflora L.). Anggraini dkk, 2013 menunjukan bahwa ekstrak air bawang merah dengan konsentrasi tinggi sebesar $75 \% \mathrm{v} / \mathrm{v}$ menurunkan berat segar kecambah padi sawah (Oriza sativa L.) sebesar $21 \%$. Kemungkinan tanaman dan organ memiliki respon yang berbeda terhadap kandungan quercetin dari ekstrak air bawang merah.

Berat kering. Rata-rata kadar air relatif polong kacang kapri setelah perlakuan ditunjukkan pada table pada Table 5

Tabel 5. Rata - rata berat kering polong kapri 3 hari setelah perlakuan (gram)

\begin{tabular}{lll}
\hline $\begin{array}{l}\text { Air } \\
\text { kelapa }\end{array}$ & $\begin{array}{l}\text { Ekstrak air } \\
\text { bawang } \\
\text { merah }\end{array}$ & $\begin{array}{l}\text { Rata-rata } \\
\overline{\mathbf{Y}} \pm \mathrm{SE}\end{array}$ \\
\hline \multirow{2}{*}{$0 \%$} & $0 \%$ & $0.26 \pm 0.03^{\mathrm{a}}$ \\
& $12.5 \%$ & $0.26 \pm 0.04^{\mathrm{a}}$ \\
& $25 \%$ & $0.09 \pm 0.03^{\mathrm{b}}$ \\
& $0 \%$ & $0.28 \pm 0.02^{\mathrm{a}}$ \\
$25 \%$ & $12.5 \%$ & $0.19 \pm 0.19^{\mathrm{a}}$ \\
& $25 \%$ & $0.07 \pm 0.01^{\mathrm{b}}$ \\
& $0 \%$ & $0.25 \pm 0.02^{\mathrm{a}}$ \\
$50 \%$ & $12.5 \%$ & $0.13 \pm 0.02^{\mathrm{a}}$ \\
& $25 \%$ & $0.11 \pm 0.01^{\mathrm{b}}$ \\
\hline
\end{tabular}

Keterangan : nilai-nilai yang diikuti oleh huruf yang sama tidak berbeda nyata

Hasil penelitian menunjukan bahwa ekstrak air bawang dengan konsentrasi $25 \%$ menurunkan berat kering dari 0.26 menjadi $0.09 \mathrm{ml} / \mathrm{g}$ jaringan atau sebesar $68 \%$. Interaksi antara ekstrak air bawang merah 25\% dengan air kelapa 25\% menurunkan kandungan klorofil total polong kacang kapri dari 0.28 menjadi $0.17 \mathrm{ml} / \mathrm{g}$ jaringan atau sebesar $45 \%$. Demikian juga interaksi antara ekstrak air bawang 25\% dengan air kelapa 50\% menurunkan kandungan klorofil total polong kacang kapri dari 0.25 menjadi $0.11 \mathrm{ml} / \mathrm{g}$ jaringan atau sebesar $56 \%$. Berat kering polong kacang kapri sangan ditentukan oleh akumulasi bahan kering. Oleh sebab itu berat kering organ sangat ditentukan oleh laju respirasi dan hidrolisis makro molekul seperti protein, 
5 / Rahma, A., Zulkifli,. Lande, M L., Nurcahyani, E.

Tabel 6. Rata - rata kadar air relatif polong kapri 3 hari setelah perlakuan (\%). $\bar{Y} \pm$ SE

\begin{tabular}{lllll}
\hline Faktor & \multicolumn{4}{c}{ Ekstrak air bawang merah } \\
\cline { 2 - 5 } Air Kelapa & Taraf $(\mathrm{v} / \mathrm{v})$ & $0 \%$ & $12,5 \%$ & $25 \%$ \\
& $0 \%$ & $71.3 \pm 9.4$ & $71.1 \pm 13.1$ & $78.0 \pm 6.9$ \\
& $25 \%$ & $60.7 \pm 6.2$ & $65.6 \pm 4.7$ & $71.5 \pm 7.2$ \\
& $50 \%$ & $64.0 \pm 2.3$ & $66.8 \pm 3.7$ & $72.8 \pm 6.4$ \\
\hline
\end{tabular}

lipid, asam nukleat dan pigmen (Watanabe at al, 2013).

Kadar air relative. Rata-rata kadar air relatif polong kacang kapri setelah perlakuan ditunjukkan pada table pada Table 6.

Analisis ragam pada taraf nyata $5 \%$ menunjukan bahwa air kelapa, ekstrak air bawang merah serta interaksinya tidak berpengaruh nyata terhadap kadar air relatif polong kacang kapri. Kadar air relatif dalam jaringan sangat bergantung pada laju transpirasi jaringan dan aktivitas hidrolisis lainnya. Hasil penelitian ini berbeda dari penelitian sebelumnya yang dilakukan oleh Anggraini dkk, 2013 terhadap padi sawah (Oriza sativa L.). konsentrasi ekstrak air bawang $75 \% \mathrm{v} / \mathrm{v}$ menurunkan kadar air relative kecambah padi sawah, seperti halnya berat segar polong kakacang kapri memiliki respon yang berbeda terhadap ekstrak air bawang merah dalam hal kadar air relative.

\section{KESIMPULAN}

Penambahan ekstrak air bawang merah tidak dapat meningkatkan kemampuan air kelapaa dalam menunda proses senescence polong kacang kapri yang ditunjukan oleh penurunan kandungan klorofil total dan berat kering.

\section{SARAN}

Perlu dilakukan penelitian ekstrak air bawang merag dengan konsentrasi yang lebih tinggi.

\section{DAFTAR PUSTAKA}

Andersen, O. M., K. R, Markham. 2006.
Flavonoids: Chemistry, Biochemistry, and Applications. CRC Press. Francis. Hal; 422.

Anggraini Karlisa. 2013. Studi Stimulasi Perkecambahan dan Pertumbuhan Kecambah Padi Sawah (Oriza Sativa L.) Varietas Inpari 30 dengan Ekstrak Air Bawang Merah (Allium Cepa L.)[Sripsi]. Universitas Lampung. Lampung

Eason, J.R. .2002. Sandersomia aurantiaca: $\mathrm{Ab}$ evaluation of postharvest pulsing solution to maximize cut flower quality. New Zealand Journal Of Crop and Horticultural Science.

Jeyapalan, J. C. and Sedivy, J. M (2008). Cellular senescence and organismal aging. Mech. Ageing Dev. 129, 467-474

Lakhanpal, P. and Rai D. K. 2007.Quercetin: A Versatile Flavonoid.internet Journal of Medical Update, Vol. 2, No2.

Silvinia Ade. 2013. Pengaruh Air Kelapa (Cocos nucifera L.), Asam Giberelat (GA3) dan Interaksinya terhadap Proses Senescence pada Bunga potong Krisan Putih (Dendranthema grandiflora L.)[Skripsi]. Universitas Lampung. Lampung

Watanabe, M., Balazadeh, S., Tohge, T., Erban, A., Giavalisco, P., Kopka, J., Mueller-Roeber, B., Fernie, A. R. and Hoefgen, R. (2013). Comprehensive dissection of spatiotemporal metabolic shifts in primary, secondary, and lipid metabolism 
developmental senescebce in Arabidopsis. Plant physiol. 162, 1290-1310.

Woodson, William R. dan Amanda S. Brandt. 1991. Role of the Gynoecium in Cytokinin-induced
Carnation Petal Senescence. J. Amer Soc. Hort. Sci

Zwack, P. J. and Rashotte, A. M. 2013. Plant Sign senescence aling and Behavior 8;7, e24737. 